\title{
ANAEROBIC DIGESTION OF DOMESTIC WASTEWATER
}

\author{
B. G. Mahendra ${ }^{1}$, Sharadreddy Patil $^{2}$ \\ ${ }^{1}$ Associate Professor, ${ }^{2}$ M.Tech Scholar, Department of Civil Engineering, Poojya Doddappa Appa College of \\ Engineering, Gulbarga - 585102, Karnataka, sharadreddy.patil@gmail.com
}

\begin{abstract}
Treatment of domestic wastewater is one of the serious problems. Various treatment technologies such as physico-chemical treatment and biological treatment are available for the treatment of domestic wastewater. Owing to the presence of high organic matter, domestic wastewater is well suited for biological treatment. As such in recent years there has been increasing interest in anaerobic treatment of wastewater. Compared to aerobic treatment, anaerobic digestion produces less biomass for the same amount of COD removal compared to aerobic treatment and produces methane up to $95 \%$ of the organic matter in the waste stream. The laboratory bench scale experiments were carried out treating domestic wastewater of Gulbarga city in fabricated anaerobic batch reactor of 10 Lts working volume. The domestic wastewater has the following characteristics (average values) $\mathrm{pH}=6.9$ to 7.95 , Total solids $=1140 \mathrm{mg} / \mathrm{L}$, Dissolved solids $=1020 \mathrm{mg} / \mathrm{L}$, Suspended solids $=120 \mathrm{mg} / \mathrm{L}$, Alkalinity $=120 \mathrm{mg} / \mathrm{L}$, Total volatile solids $=890 \mathrm{mg} / \mathrm{L}$, Chloride $=262.2 \mathrm{mg} / \mathrm{L}, \mathrm{BOD}=285 \mathrm{mg} / \mathrm{L}, \mathrm{COD}=945$ $\mathrm{mg} / \mathrm{L}$. The experiments were carried out for three months with the initial organic loading rate $=0.945 \mathrm{~kg}$ of $C O D / \mathrm{m}^{3} \mathrm{day}$. From the study it is concluded that the anaerobic digestion has the efficiency in removal of COD by $90.25 \%$ and Total solids removal of $67.27 \%$.
\end{abstract}

Keywords: Domestic wastewater, anaerobic digestion.

\section{INTRODUCTION}

Poorly treated or untreated domestic wastewater with high levels of pollutants creates major environmental problems when discharged into surface water or land. Such problems may include contamination and deoxygenating of streams and waterways by direct discharge of inadequately treated wastewater [3]. Excessive concentration of nutrients such as nitrogen and phosphorus on wastewater contribute to excessive growth of plants and algal blooms in surface water bodies, which makes the downstream water unsuitable for domestic, agriculture and industrial use. The domestic wastewater contains pathogen which leads to the spread of diseases and odour, when discharged in water bodies or on land for irrigation without any treatment. Over application of domestic wastewater to land results in damage to soil, crops, and contamination of ground water, clogging of soil pores by solids present in wastewater [4].

Domestic wastewater is characterized by low biological oxygen demand (BOD) and chemical oxygen demand (COD) concentrations, turbid, low/high $\mathrm{pH}$. The domestic wastewater contains chlorides, very small amount of solids, oils, fats and detergents and sanitizing agents, as such it requires treatment [2].

The present study was carried out in the Environmental Engineering laboratory, Civil Engineering department,
PDA Engineering College, Gulbarga, from the period July 2012 to December 2012, with the following objectives.

1) To determine the characteristics of domestic wastewater.

2) To study the different stages of anaerobic digestion process.

3) To study the anaerobic digestion under optimum condition.

4) To study the effect of organic loading on the performance of anaerobic digestion process.

\subsection{Microbiology of Anaerobic Digestion:}

The biochemistry and kinetics of anaerobic process are complicated and the biological conversion of organic matter into methane is brought about by a group of specific micro organisms. The schematics of the process as described by Gujer, Zehnder (1983) involving the hydrolysis of biopolymers such as carbohydrates, lipids and proteins, oxidation and fermentation of amino acids and sugars, fatty acids, alcohol's and intermediates and the conversion of acetate and hydrogen into methane are schematically represented in the following figure 1 [1]. 


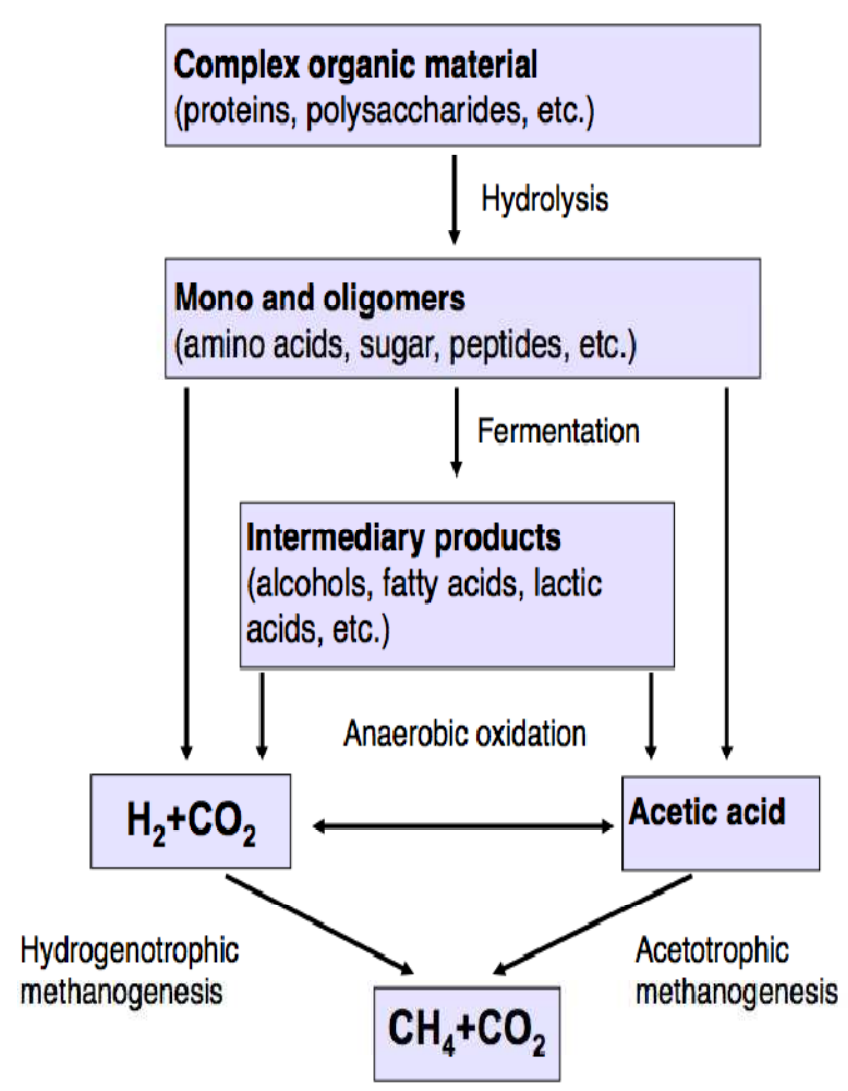

Figure 1: Breakdown of organic polymers in anaerobic digestion.

\section{MATERIAL AND METHODOLOGY}

The laboratory bench scale Batch reactor experiments were carried for treating domestic wastewater of Gulbarga city. As per provisional reports of Census of India, population of Gulbarga city in $2011 \mathrm{AD}$ is 5,32,031 and the out flow of domestic wastewater is 55 MLD. The study was conducted under ambient environmental conditions in fabricated anaerobic reactor of 10 Lts working volume. The domestic wastewater was collected from Nagenahalli nala, NH 218, 2 KM away from PDA college of engineering, towards south of Gulbarga city.

During the start up of reactor it was fed with domestic wastewater of $10 \mathrm{Lts}$ having COD of $945 \mathrm{mg} / \mathrm{L}$ at organic loading rate $0.945 \mathrm{~kg} \mathrm{COD} / \mathrm{m} 3 \mathrm{~d}$ at room temperature and operated for 90 days. The domestic wastewater characteristics were analysed as per "standard methods for the examination of water and wastewater" (21st edition, 2005) [5].

\section{RESULTS AND DISCUSSION}

The domestic wastewater was analysed for the following parameters such as $\mathrm{pH}, \mathrm{BOD}, \mathrm{COD}$, alkalinity, total solids, suspended solids, dissolved solids, total volatile solids and chlorides and the same presented in table 1. Anaerobic digestion of domestic wastewater was conducted in batch reactor. The study was conducted at laboratory temperature varying from $25-30{ }^{\circ} \mathrm{C}$. The data collected during the study period are discussed in the following section.

Table 1: Characteristics of domestic wastewater

\begin{tabular}{|c|l|c|c|}
\hline S No & Parameters & Unit & Value \\
\hline 1 & pH & - & $7.6-7.3$ \\
\hline 2 & Alkalinity as $\mathrm{CaCO}_{3}$ & $\mathrm{mg} / \mathrm{L}$ & $146-135$ \\
\hline 3 & Total solids & $\mathrm{mg} / \mathrm{L}$ & $1172-1119$ \\
\hline 4 & Dissolved solids & $\mathrm{mg} / \mathrm{L}$ & $1054-995$ \\
\hline 5 & Suspended solids & $\mathrm{mg} / \mathrm{L}$ & $126-111$ \\
\hline 6 & Total volatile solids & $\mathrm{mg} / \mathrm{L}$ & $901-879$ \\
\hline 7 & Chlorides as $\mathrm{Cl}_{2}$ & $\mathrm{mg} / \mathrm{L}$ & $276.2-251$ \\
\hline 8 & COD & $\mathrm{mg} / \mathrm{L}$ & $955-935$ \\
\hline 9 & BOD $_{5}$ at $20{ }^{\circ} \mathrm{C}$ & $\mathrm{mg} / \mathrm{L}$ & $298-276$ \\
\hline
\end{tabular}

The percentage of COD removal and biogas produced with per $\mathrm{kg}$ of COD removed are shown in table 2 and presented in figure 2 . The percentage of total solids removal and volume of biogas produced per $\mathrm{kg}$ of total solids removal are shown in table 3 and presented in figure 3 . The biogas produced (in LPD) during day 10 to day 90 shown in table 4 and presented in figure 4. 
Table 2: COD, percentage of COD removal and volume of Biogas produced per kg of COD removal during day 10 to day 90

\begin{tabular}{|c|c|c|c|c|}
\hline S No & $\begin{array}{c}\text { Experimental } \\
\text { periods in days }\end{array}$ & $\begin{array}{c}\text { COD } \\
(\mathbf{m g} / \mathbf{L})\end{array}$ & $\begin{array}{c}\text { Percentage of } \\
\text { COD removal }\end{array}$ & $\begin{array}{c}\text { Volume of Biogas produced per kg of } \\
\text { COD removal (in Lts) }\end{array}$ \\
\hline 1 & 10 & 892.1 & 5.6 & 35.85 \\
\hline 2 & 20 & 795 & 15.87 & 20.66 \\
\hline 3 & 30 & 697.5 & 26.19 & 19.79 \\
\hline 4 & 40 & 591.8 & 37.37 & 18.68 \\
\hline 5 & 50 & 492 & 47.94 & 17.88 \\
\hline 6 & 60 & 393.3 & 58.38 & 16.67 \\
\hline 7 & 70 & 294.4 & 68.85 & 15.83 \\
\hline 8 & 80 & 193.1 & 79.57 & 14.49 \\
\hline 9 & 90 & 92.1 & 90.25 & 14.30 \\
\hline
\end{tabular}

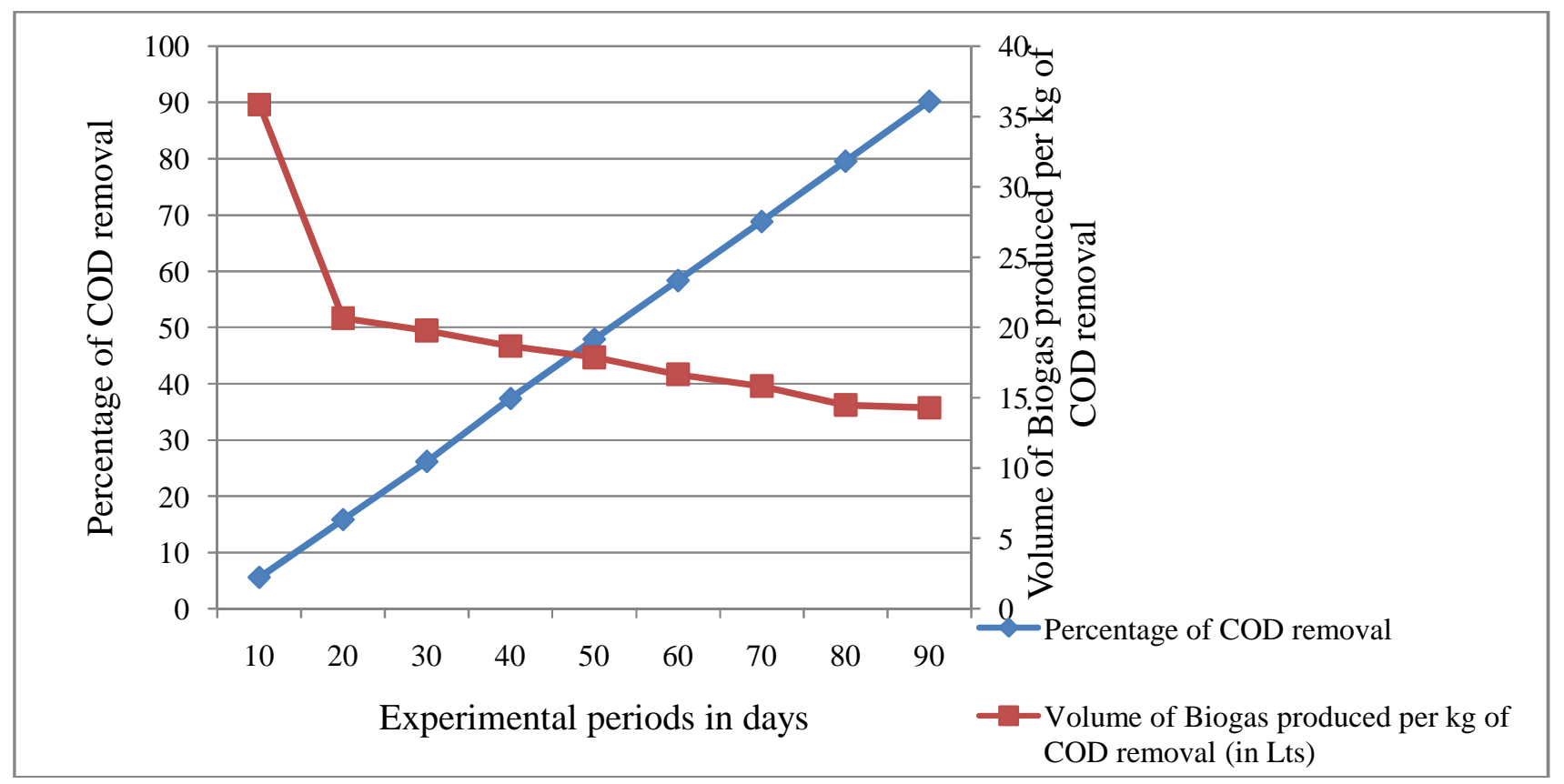

Figure 2: Percentage of COD removal and volume of Biogas produced per kg of COD removal during day 10 to day 90

Table 3: Total solids, percentage of Total solids removal and volume of Biogas produced per kg of Total solids removal during day 10 to day 90

\begin{tabular}{|c|c|c|c|c|}
\hline S No & $\begin{array}{c}\text { Experimental } \\
\text { periods in days }\end{array}$ & $\begin{array}{c}\text { Total } \\
\text { solids } \\
(\mathbf{m g} / \mathbf{L})\end{array}$ & $\begin{array}{c}\text { Percentage of Total } \\
\text { solids removal }\end{array}$ & $\begin{array}{c}\text { Volume of Biogas produced per kg of } \\
\text { Total solids removal } \\
\text { (in Lts) }\end{array}$ \\
\hline 1 & 10 & 1053.8 & 7.56 & 22.04 \\
\hline 2 & 20 & 968.9 & 15.01 & 18.12 \\
\hline 3 & 30 & 883.7 & 22.48 & 19.11 \\
\hline 4 & 40 & 794.6 & 30.30 & 19.11 \\
\hline
\end{tabular}




\begin{tabular}{|c|c|c|c|c|}
\hline 5 & 50 & 710.1 & 37.71 & 18.84 \\
\hline 6 & 60 & 625.3 & 45.15 & 17.87 \\
\hline 7 & 70 & 537 & 52.89 & 15.91 \\
\hline 8 & 80 & 454.7 & 60.11 & 15.91 \\
\hline 9 & 90 & 373.1 & 67.27 & \\
\hline
\end{tabular}

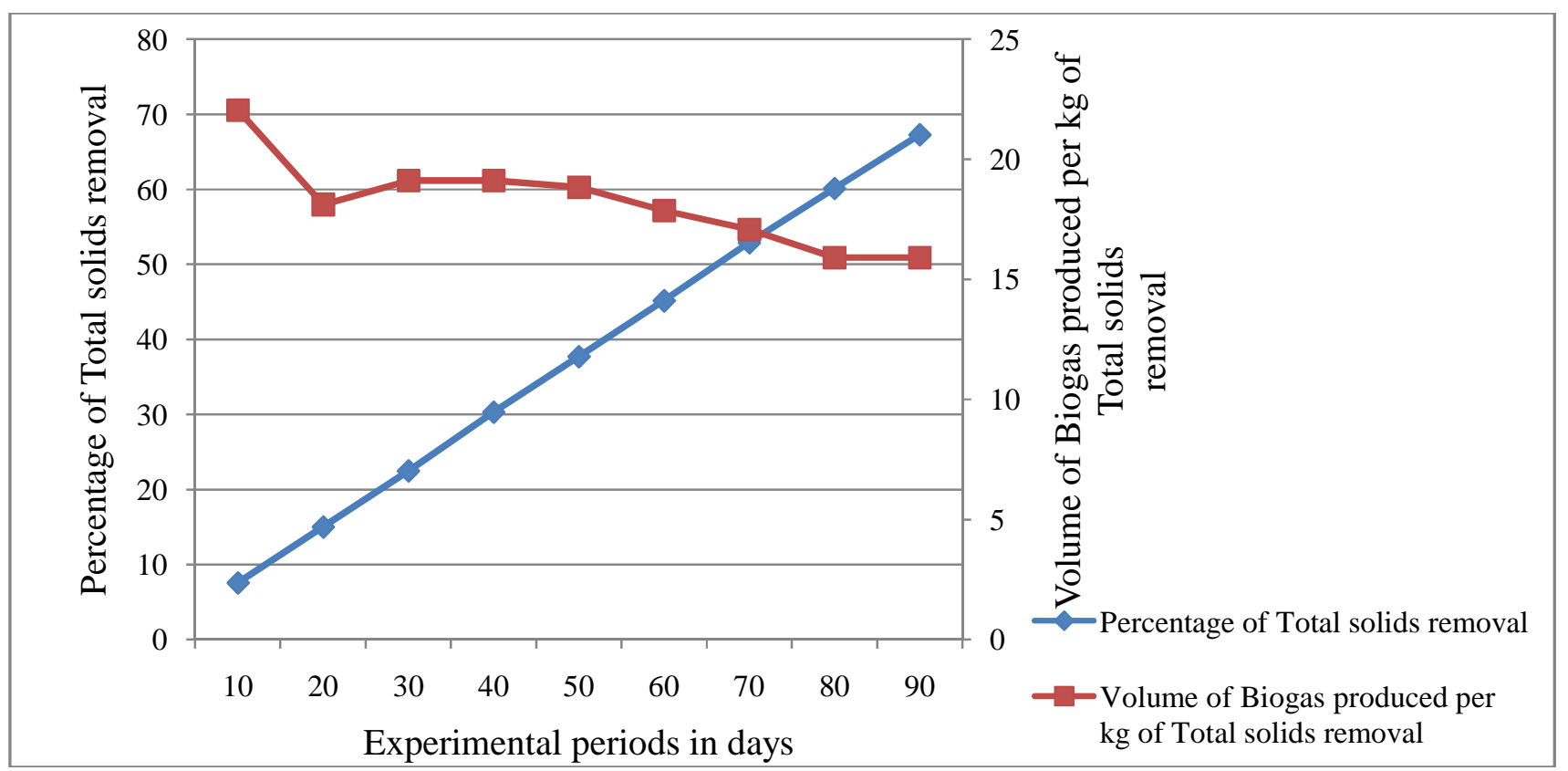

Figure 3: Percentage of Total solids removal and volume of Biogas produced per $\mathrm{kg}$ of Total solids removal during day 10 to day 90

Table 4: Biogas production during day 10 to day 90

\begin{tabular}{|c|c|c|}
\hline S No & Experimental periods in days & Biogas produced in LPD \\
\hline 1 & 10 & 0.019 \\
\hline 2 & 20 & 0.031 \\
\hline 3 & 30 & 0.049 \\
\hline 4 & 40 & 0.066 \\
\hline 5 & 50 & 0.081 \\
\hline 6 & 60 & 0.092 \\
\hline 7 & 70 & 0.103 \\
\hline 8 & 80 & 0.109 \\
\hline 9 & 90 & 0.122 \\
\hline
\end{tabular}




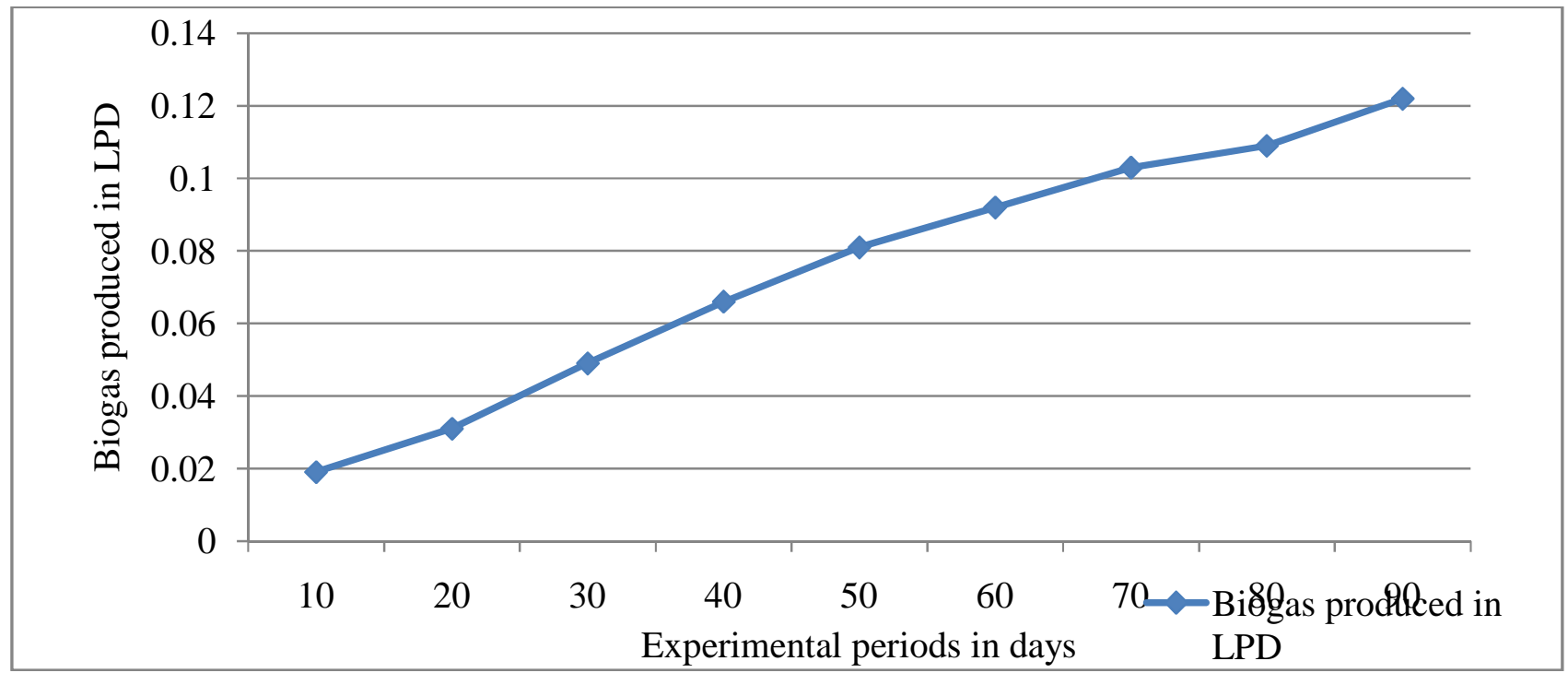

Figure 4: Biogas production during day 10 to day 90

\section{CONCLUSIONS}

Based on the experimental study following conclusions can be drawn

1. It can be concluded from characterization study that the wastewater is highly organic in nature having high value of COD.

2. The maximum COD removal efficiency is 90.25 percent.

3. The maximum total solids removal efficiency is 67.27 percent.

4. The maximum biogas produced is 0.122 LPD on the $90^{\text {th }}$ day.

\section{REFERENCES}

[1] Anna Schnurer and Asa Jarvis - Microbiological handbook for biogas plants, Swedish waste management U2009 march, Swedish Gas Centre report 207.

[2] Cheerawit R, Thunwadee T. S, Duangporn K, Tanwat R and Wichuda - Biogas Production from Co - digestion of domestic wastewater and food waste, Health and the Environmental Journal, 2012, Volume 3, no. 2.

[3] I. Bodik, S. sedlacek, M. Kulaska and M. Hutnan Biogas Production in Muncipal Wastewater Treatment Plants, Chemical and Biochemical Engineering, Q. 25(3), 335 - 340 (2011).

[4] Metcalf and Eddy - Wastewater Engineering Treatment and Reuse, $4^{\text {th }}$ edition, McGraw - Hill Publishing, New York - 2004.

[5] Standard Methods for the examination of Water and Wastewater, $21^{\text {st }}$ edition (APHA, AWWA AND WFF, Washington DC) 2005. 